\title{
The Nexus between Urbanization, Gross Capital Formation and Economic Growth: A Study of Saudi Arabia*
}

\author{
Uzma KHAN $^{1}$
}

Received: September 10, 2020 Revised: November 08, 2020 Accepted: November 16, 2020

\begin{abstract}
To investigate the nexus between urban population, gross capital formation, and economic growth in the Kingdom of Saudi Arabia, yearly data was collected from the World Bank for the period 1974- 2018. Basic statistics test and correlation matrix was used to investigate the causal effect among the tested parameters, followed by Augmented Dickey-Fuller (ADF) stationary test, co-integration analysis by Johansen test after that Vector Auto-Correction Model for both short-run and long-run and finally the Granger-Causality tests. Result of unit root test analysis shows that the urban population became stationary at I (0) level while economic growth and gross capital formation became stationary at I (1). Johansen co-integration analysis indicates that there is presence of both long-run and short-run relationship between the three variables in the Kingdom of Saudi Arabia. The result of the VECM Model reflects that both economic growth and gross capital formation have a negative impact on urban population in the short run. According to the Granger-Causality tests, there is unidirectional causality with the urban population by both gross capital formation and economic growth. Also, the result of the Granger Causality tests show that there is unidirectional causality between economic growth and gross capital formations.
\end{abstract}

Keywords: Urbanisation, Gross Capital Formation, Economic growth, VECM, Granger Casualty

JEL Classification Code: C01, C22, C87, O53

\section{Introduction}

Urbanisation is regarded as a catalyst for economic growth and development if it is managed efficiently; it can open doors for further sustainable economic growth. It is a process taking place globally intertwined with economic growth and development. Throughout civilization's history, urbanisation has been a key element in the enhancement progression (Bairoch, 1988). Arguably, the two procedures are interdependent, improvement now no longer takes place without urbanisation and vice versa. However, causal

\section{*Acknowledgements:}

This study is supported by Dean Scientific Research at Prince Sattam Bin Abdulaziz University Al-kharj, Kingdom of Saudi Arabia. ${ }^{1}$ First Author and Corresponding Author. Assistant Professor, College of Business Administration, Female Campus, Prince Sattam Bin Abdulaziz University, Saudi Arabia [Postal Address: Alkharj, Riyadh, 11942, Kingdom of Saudi Arabia]

Email: uzmakhanafridi@gmail.com; u.khan@psau.edu.sa

() Copyright: The Author(s)

This is an Open Access article distributed under the terms of the Creative Commons Attribution Non-Commercial License (https://creativecommons.org/licenses/by-nc/4.0/) which permits unrestricted non-commercial use, distribution, and reproduction in any medium, provided the original work is properly cited. causation among those procedures isn't always clear (Jacobs, 1969). As per the United Nation Department of Economic and Social Affairs, (UNDESA) report of 2018 revision of world urbanisation prospects suggests that $55 \%$ of the world population lives in the urban areas, a proportion that is expected to increase to $68 \%$ by 2050 .

Saudi Arabia has witnessed rapid urbanisation as 21\% of the population lived in urban areas in 1950, has increased to $58 \%$ in 1975 , further increased to $83 \%$ in 2015 . According to the report of Trade Arabia (2015), rapid urbanisation, expected to add about seven million to Saudi Arabia's urban population by 2025 . The UN world urbanisation prospect report (2018) stated that urbanisation in Saudi Arabia is expected to reach $86 \%$ by 2030 and $90 \%$ by 2050 .

Earlier facts, in addition to statistics, revealed that the majority of the advanced nations have a better stage of GDP per capita as well as they are at a better stage in terms of urbanisation. It is normally widely accepted that economic growth increased the growth of present-day industrialisation and hence also caused the growth of the urban population; in turn, urbanisation additionally promotes economic growth to some extent. Many of the developing nations are speeding up urbanisation for quick economic growth. Policies for swift 
urbanisation to boost economic growth has been widely observed in the underdeveloped economies (Chen 2014).

The focus of world urbanisation has shifted towards the developing countries from the developed nations. As rapid urbanisation takes place around the globe, it is likely to create speedy growth prospects in the Kingdom too, which will eventually lead to sustainable economic growth and development.

\section{Literature Review}

Available literatures reflect that urbanisation and urban concentration have a positive impact on economic growth, whereas urban primacy harms economic growth (Chang 2006, Njoh 2003, Moomaw 1996, Moomaw 1993). The argument that urbanisation encourages economic growth has recently been challenged by a report showing that there is not sufficient evidence to prove that urbanisation level affects economic progress rate (Bloom, Canning and Fink, 2008). Afroz et al. (2020) found that information and communication technology (ICT) has a positive as well as a significant impact on the health condition of the general population in both long-run and the short-run, while economic growth does not have a noteworthy impact on population health conditions as per the Bounds test analysis. Turok and McGranahan (2013) have also supported the argument that urbanisation does not have a connection with economic growth by arguing that it is not urbanisation or city size that encourages economic growth, rather it is the infrastructure and institutional settings that make an impact on economic growth.

Mei (2014) argued that urbanisation cannot play a momentous role in stimulating economic growth until the 21 st century. Also, economic growth cannot significantly increase urbanisation, although it supports urbanisation, but only in the short-run. Therefore, this study is an attempt to highlight the importance of the affiliation between urbanisation and economic growth, along with the addition of gross capital formation and makes us rethink about the popular idea that urbanisation is associated with economic growth and development.

Nguyen and Nguyen (2017) found that urbanisation has a positive impact on economic growth. The Granger causality test, the regression estimation method with static and dynamic panel data were used to find out the association. However, the association among urbanisation and economic growth was found to be non-linear. The urbanisation reaches a threshold after which it may impede economic growth. The estimated threshold is $69.99 \%$ for the static model and $67.94 \%$ for the dynamic model.

Zhao and Wang (2015) empirically tried to investigate the various effects of urbanisation, economic growth and the energy consumption in China. However, Granger causality test revealed that there is dual causation among energy consumption and economic growth, and one-way causality running from urbanisation to energy consumption and economic growth to urbanisation.

Asif et al. (2015) explored the nexus among economic growth, urbanisation, energy consumption and carbon dioxide emission in GCC countries where they identified urbanisation to have a strong effect on carbon dioxide emission, energy consumption and economic growth. Economic growth has a strong effect on carbon dioxide emission, but has a negative effect on energy consumption. Energy consumption has a strong effect on carbon dioxide emission, while carbon dioxide emission has a strong effect on energy consumption and economic growth. Further, they came to the conclusion by suggesting that to achieve sustainable development goals for GCC countries, urban planning and clean energy consumption must be adopted.

Nguyen et al. (2020) explored the role of urbanisation and economic growth in reducing the rate of poverty in Vietnam and for this purpose relevant data for a time period of 8 years was analysed. They found that the factors with a significant negative impact on the poverty rate are imports value, urbanisation rate and employment rate; and the factors that do not affect the poverty rate are exports value and GDP value. Turok and McGranahan (2020) tried to develop a nexus among urbanisation and the economic growth rate in Africa and Asia. However, they found no visible association among urbanisation and economic growth or between city size and productivity after analyzing relevant data. Choi et al. (2020) suggested that the smart city has emerged as one of the ways out to countless upcoming urban glitches to overcome the urban issues created by global warming, energy problems, and increasing population. It is expected that smart cityrelated industries will now be the main industries of any nation and will be actively utilized to drive economic growth as well.

The objective of this study is to form an econometric model that reconnoiters the nexus between Urban Population, Gross Capital Formation, and economic growth in the Kingdom of Saudi Arabia. In particular, the aim is to explore a response to the hypothesis of:

i. To examine whether Urban Population leads to economic growth.

ii. To evaluate whether Gross Capital Formation leads to economic growth.

iii. To analyze whether economic growth leads to both Urban Population and Gross Capital Formation.

iv. To explore whether Urban Population and Gross Capital formation have any causal relationship. 


\section{Data and Methodology}

Yearly time series data which had 45 observations from 1974 to 2018 and which was adequate to capture the short-run and long-run association among Urban Population, Gross Capital Formation, and Economic Growth in the model was used. The data set consisted of observations for GDP (current US\$) as an economic growth indicator, Urban Population Urban and Gross Capital formation (current US\$). All data sets were taken from World Development Indicators 2019.

The first step is to determine the degree of integration of each variable. It is observed if all the variables are integrated into the level and apply to an estimation based on linear regression. On the other hand, if all the variables are integrated at first difference or second difference, our estimates will be based on an estimate of the Vector Auto-Regressive (VAR) model. The absence of co-integration relation will lead to a VAR model, and the presence of a co-integration relation between the different variables studied will lead to the Vector Error Correction Model (VECM).

\section{Results}

The model for the present study can be expressed by having ceteris paribus assumption as:

\section{Urban Population $=f$ (Economic Growth, Gross Capital Formation)}

All the variables are used in a real term and transformed into logarithmic function:

$$
\ln Y_{t}=\log Y_{t}
$$

This can also be represented in a log-linear econometric format as:

$$
\operatorname{lnup}_{t}=\beta_{0}+\beta_{1} \operatorname{lngdp_{t}}+\beta_{2} \operatorname{lngcf}+\varepsilon_{t}
$$

Where, $\beta_{0}$ : constant term, $\beta_{1}$ : coefficient of a variable (exports), $\beta_{2}$ : coefficient of variables (imports), $t$ : The time trend and $\varepsilon_{\mathrm{t}}$ : The random error term assumed to be normal, identically and independently distributed.

The Long run model can be expressed as:

$$
\operatorname{lnup} p_{t}=a_{0}+a_{1} \operatorname{lng} d p_{t}+a_{2} \operatorname{lng} c f_{t}+\varepsilon_{t}
$$

In the short run our model can be expressed as:

$$
\begin{aligned}
\Delta \operatorname{lnup}_{t}= & a+\sum_{i=1}^{k-1} \beta_{i} \Delta \operatorname{lnup} p_{t-i}+\sum_{j=1}^{k-1} \varnothing_{j} \Delta \operatorname{lng} d p_{t-j} \\
& +\sum_{m=1}^{k-1} \theta_{m} \Delta \operatorname{lng} c f_{t-m}+\lambda_{1} E C T_{t-1}+\mathfrak{u}_{1 t} \\
\Delta \operatorname{lng} d p_{t}= & \sigma+\sum_{i=1}^{k-1} \beta_{i} \Delta \operatorname{lnup} p_{t-i}+\sum_{j=1}^{k-1} \varnothing_{j} \Delta \operatorname{lng} d p_{t-j} \\
& +\sum_{m=1}^{k-1} \theta_{m} \Delta \operatorname{lng} c f_{t-m}+\lambda_{2} E C T_{t-1}+\mathfrak{u}_{2 t} \\
\Delta \operatorname{lng} g f_{t}= & \partial+\sum_{i=1}^{k-1} \beta_{i} \Delta \operatorname{lnup} p_{t-i}+\sum_{j=1}^{k-1} \varnothing_{j} \Delta \operatorname{lng} d p_{t-j} \\
& +\sum_{m=1}^{k-1} \theta_{m} \Delta \operatorname{lng} g f_{t-m}+\lambda_{3} E C T_{t-1}+\mathfrak{u}_{3 t}
\end{aligned}
$$

Where;

- $\operatorname{lnup}=\log$ value of Urban Population

- $\operatorname{lng} d p=\log$ value of Economic Growth measured in terms of GDP

- $\operatorname{lngcf}=\log$ value of Gross Capital Formation

- $k-1=$ the optimal lag length is reduced by 1

- $\beta_{\mathrm{i}}, \varnothing_{\mathrm{j}}, \theta_{\mathrm{m}}=$ short-run dynamic coefficients of the model's adjustment long-run equilibrium

- $\lambda_{\mathrm{i}}=$ speed of adjustment parameter with a negative sign

- $E C T_{t-1}=$ the error correction term is the lagged value of the residuals that contains long-run information resulting from the long-run co-integrating relationship.

- $u_{i t}=$ residuals in the equations

Table 1 represents the descriptive statistics of the selected parameters that need to be investigated in this study and the correlation coefficient matrix showing the positive correlation among the variables. It is found that the dependent variable urban population (LNUP) and the independent variable economic growth (LNGDP) are positively correlated with a correlation coefficient equal to $(0.865674)$. Thus, if the urban population increases by $1 \%$ then the gross domestic product (GDP) increases by $0.865674 \%$, another independent variable which is the gross capital formation (LNGCF) is also positively correlated with a correlation coefficient equal to $(0.775937)$. So, if the urban population increases by $1 \%$, the gross capital formation (LNGCF) increases by $0.775937 \%$.

Table 1: Simple Descriptive Statistics and Correlation Matrix

\begin{tabular}{|l|c|c|c|c|c|c|c|c|c|}
\hline & Mean & Median & Maximum & Minimum & Std. Dev. & Skewness & LNUP & LNGDP & LNGCF \\
\hline LNUP & 16.40702 & 16.52487 & 17.15679 & 15.20186 & 0.552867 & -0.62696 & 1 & 0.866 & 0.776 \\
\hline LNGDP & 26.00989 & 25.80911 & 27.39089 & 24.53906 & 0.814575 & 0.318628 & 0.866 & 1 & 0.97326 \\
\hline LNGCF & 24.57585 & 24.32355 & 26.1606 & 22.81976 & 0.90365 & 0.464709 & 0.776 & 0.97326 & 1 \\
\hline
\end{tabular}


The time series for the urban population is stationary at I (0) level while the other series is stationary at I (1) order difference means that by accepting the alternate hypothesis having a 2 lag length criteria, i.e. the series has no unit root at 2 lag order, we can now proceed further for the relevant test.

Table 2 represents the Johansen co-integration test results which indicate that in the long run, Economic growth (lngdp) has a positive impact while gross capital formation (lngcf) harms urban population (lnup), on an average, ceteris paribus. The coefficients are statistically significant at $1 \%$ level. In conclusion, the null hypothesis of no co-integration is rejected against then alternative of a cointegration relationship in the model.

Co-integration test result shows co-integrating equation at the 0.05 level and provides the existence of both short-run and long-run association among urban population, economic growth and gross capital formation, which can be expressed as:

$$
\operatorname{lnup}=1.1797589(\operatorname{lng} d p)-1.182715(\operatorname{lng} c f)
$$

Based on the Johansen co-integration test reveals that the three variables are co-integrated, which obliges us to use the
VEC model for a further test of significance. The long-run VEC model can be expressed as:

$$
\begin{aligned}
E C T_{t-1}= & {\left[Y_{t-1}-\eta_{j} \chi_{t-1}-\xi_{m} R_{t-1}\right] } \\
E C T_{t-1}= & 1.00 \operatorname{lnup}_{t-1}-1.191828 \operatorname{lng} d p_{t-1} \\
& +0.692053 \operatorname{lng} c f_{t-1}-2.420590
\end{aligned}
$$

The short-run equation model can be expressed as:

$$
\begin{aligned}
\Delta \operatorname{lnup}_{t}= & -0.007341 E C T_{t-1}+0.909619 \operatorname{lnup}_{t-1} \\
& +0.002681 \operatorname{lng} d p_{t-1}+0.002958 \operatorname{lng} c f_{t-1} \\
& +0.002356
\end{aligned}
$$

The conclusion from the above equations can be drawn as previous year deviation from long-run equilibrium is correlated at a speed of $0.734 \%$. A percentage change in economic growth is associated with $0.268 \%$ decrease in an

\begin{tabular}{|c|c|c|c|c|c|c|c|c|}
\hline & Eigenvalue & $\begin{array}{c}\text { Trace } \\
\text { Statistics }\end{array}$ & $\begin{array}{l}0.05 \text { Critical } \\
\text { Value }\end{array}$ & Prob.* & $\begin{array}{c}\text { Max-Eigen } \\
\text { Statistics }\end{array}$ & $\begin{array}{c}0.05 \\
\text { Critical } \\
\text { Value }\end{array}$ & Prob.* & Decision \\
\hline None & 0.632544 & 56.1933 & 29.7971 & 0.000 & 42.04832 & 21.13162 & 0.000 & \\
\hline At most 1 & 0.240874 & 14.1449 & 15.4947 & 0.079 & 11.57468 & 14.2646 & 0.128 & \\
\hline At most 2 & 0.059362 & 2.57026 & 3.84147 & 0.109 & 2.570262 & 3.84147 & 0.109 & Long Run \\
\hline \multicolumn{3}{|l|}{ LNUP } & \multicolumn{3}{|c|}{ LNGDP } & \multicolumn{2}{|c|}{ LNGCF } & \\
\hline \multirow{2}{*}{\multicolumn{3}{|c|}{1}} & \multicolumn{3}{|c|}{-1.1797859} & \multicolumn{2}{|c|}{1.182715} & \\
\hline & & & \multicolumn{3}{|c|}{0.14564} & \multicolumn{2}{|c|}{0.11922} & \\
\hline
\end{tabular}
urban population, on an average ceteris paribus in the shortrun. Moreover, a percentage change in gross capital formation is associated with $0.2958 \%$ decrease in an urban population on an average ceteris paribus in the short-run. Table 6 delineates that the model is normally distributed and stable.

Table 2: Johansen Co-integration Test for UP as a dependent variable

Table 3: VEC Granger Causality/Block Exogeneity Wald Test

\begin{tabular}{|l|c|c|c|c|c|}
\hline Dependent variable & Independent variable & Chi-sq & Df & Prob. & Decision \\
\hline \multirow{3}{*}{ LNUP } & LNGDP & 0.39238 & 1 & 0.5311 & Insignificant \\
\hline \multirow{3}{*}{ LNGDP } & LNGCF & 1.978168 & 1 & 0.1596 & Insignificant \\
\hline \multirow{3}{*}{ LNGCF } & LNUP & 0.878916 & 1 & 0.3485 & Insignificant \\
\cline { 2 - 6 } & LNGCF & 0.914552 & 1 & 0.3389 & Insignificant \\
\cline { 2 - 6 } & LNUP & 9.77045 & 1 & 0.0018 & Significant \\
\cline { 2 - 6 } & LNGDP & 0.034751 & 1 & 0.8521 & Insignificant \\
\hline
\end{tabular}


Table 4: Pairwise Granger Causality Test

\begin{tabular}{|c|c|c|c|c|}
\hline Null Hypothesis & Observations & F-Statistic & Prob.* & Decision \\
\hline LNGDP does not Granger Cause LNUP & \multirow{2}{*}{43} & 17.0504 & 5.E-06 & Accepted \\
\hline LNUP does not Granger Cause LNGDP & & 1.02536 & 0.3684 & Rejected \\
\hline LNGCF does not Granger Cause LNUP & \multirow{2}{*}{43} & 10.8573 & 0.0002 & Accepted \\
\hline LNUP does not Granger Cause LNGCF & & 1.98882 & 0.1509 & Rejected \\
\hline LNGCF does not Granger Cause LNGDP & \multirow{2}{*}{43} & 0.45405 & 0.6385 & Rejected \\
\hline LNGDP does not Granger Cause LNGCF & & 4.59771 & 0.0163 & Accepted \\
\hline
\end{tabular}

Table 5: Summary of VEC Outcomes

\begin{tabular}{|l|l|l|l|}
\hline Dependent & \multicolumn{1}{|c|}{ t-Statistics Test } & \multicolumn{1}{|c|}{ Wald Coefficient Test } & \multicolumn{1}{c|}{ Pairwise Granger Causality Test } \\
\hline LNUP & Long-run causal effect & Insignificant & Insignificant \\
\hline LNGDP & Insignificant & Insignificant & $\begin{array}{l}\text { LNGDP Granger Cause LNUP } \\
\text { LNGDP Granger Cause LNGCF }\end{array}$ \\
\hline LNGCF & $\begin{array}{l}\text { Long-run causal effect. } \\
\text { short-run effect towards urban } \\
\text { population }\end{array}$ & $\begin{array}{l}\text { Short-run urban population } \\
\text { significant }\end{array}$ & LNGCF Granger Cause LNUP \\
\hline
\end{tabular}

Table 6: Diagonostic test

\begin{tabular}{|c|c|c|c|c|}
\hline \multicolumn{3}{|c|}{ VEC Residual Heteroskedasticity Tests } & \multicolumn{2}{|c|}{ Inference } \\
\hline Chi-sq & Df & Prob. & \multirow{2}{*}{\multicolumn{2}{|c|}{ Homoskedasticity }} \\
\hline 63.9728 & 48 & 0.0612 & & \\
\hline \multicolumn{3}{|c|}{ VEC Residual Normality Tests } & & \\
\hline Jarque-Bera & Df & Prob. & \multirow{2}{*}{\multicolumn{2}{|c|}{ Significant }} \\
\hline 4.051467 & 6 & 0.6697 & & \\
\hline \multicolumn{3}{|c|}{ Table 11 VEC Residual Serial Correlation LM Tests } & & \\
\hline & & Df & Prob. & \\
\hline LRE*stat & 37.3482 & 9 & 0 & \multirow{2}{*}{$\begin{array}{c}\text { Serial } \\
\text { Correlation }\end{array}$} \\
\hline Rao F-stat & 5.008411 & $9,80.5$ & 0 & \\
\hline
\end{tabular}

\section{Conclusion}

This paper is based on the twofold investigation method. Firstly, it investigates the association among urban population, economic growth and gross capital formation for the Kingdom of Saudi Arabia, secondly, if such a relationship exists and needs to be investigated in the direction of causality for that model.

To achieve our purpose, time series yearly data was collected from the World Bank for the period from 1974 to 2018 , which was tested by using correlation test to develop a relationship, followed by Augmented DickeyFuller (ADF) stationary test to check whether the series is stationary and if so then at what degree, further Johansen co-integration analysis was done, which leads to predict the nature of Vector Error Correction Model (VECM) and its causal effects. As per our analysis, the test of correlation shows the association among the variables to be strongly associated. While the ADF unit root test signifies that the urban population is stationary at I (0) level while others become stationary at I (1) level. Also, it was determined by Johansen co-integration analysis that there is co-integration among the variables, which means that in both long-run and short-run there is a relationship among the three variables in Saudi Arabia. However, gross capital formation harms the urban population, while economic growth has a positive effect on the urban population with the assumption of ceteris paribus. 
Vector Error Correction Model indicates that there is significant long-run causal effect among the variables but in short-run causal effect is insignificant. Granger Causality Test indicates the direction of their causal effect among variables. The results of our analysis indicate that there is a unidirectional causal effect from economic growth to urban population, as well as unidirectional causal effect flowing from economic growth to gross capital formation. Hence, economic growth has a unidirectional causal effect on both of these variables ceteris paribus. More interestingly, it was gross capital formation which promotes the urban population, and the direction of flow is unidirectional from gross capital formation to the urban population. Hence economic growth, as well as gross capital formation, leads to the urban population. Finally, the conclusion can be drawn as this model proves the hypothesis (iii) and (iv) to be true as well as statistically significant.

This study is based on time series analysis for a specific period as well as for a specific country and is also based on an Ordinary Least Square technique with the assured assumption of ceteris paribus.

\section{References}

Afroz, R., Muhibbullah, M., \& Morshed, M. N. (2020). Impact of Information and Communication Technology on Economic Growth and Population Health in Malaysia. Journal of Asian Finance, Economics and Business, 7(4), 155-162. https://doi. org/10.13106/jafeb.2020.vol7.no4.155

Asif, M, Sharma, R. B, \& Adow, A. H. E. (2015). An Empirical Investigation of the Relationship between Economic Growth, Urbanization, Energy Consumption, and $\mathrm{CO}_{2}$ Emission in GCC Countries: A panel data analysis. Asian Social Science, 11(21). http://dx.doi.org/10.5539/ass.v11n21p270

Choi, C., Choi, J., Kim, C., \& Lee, D. (2020). The Smart City Evolution in South Korea: Findings from Big Data Analytics.
Journal of Asian Finance, Economics and Business, 7(1), 301-311. https://doi.org/10.13106/jafeb.2020.vol7.no1.301

Jacobs, J. (1969). The Economy of Cities. New York, NY: Random House.

Mei, X. (2014). Research on the relationship between urbanisation and economic growth in China-econometric analysis based on data from 1952-2013. Bio Technology an Indian Journal, 10(22), 13949-13954.

Moomaw, R., \& Shatter, A. M. (1993). Urbanisation as a Factor in Economic Growth. Journal of Economics, 19, 1-6.

Moomaw, R. L., \& Shatter, A. M. (1996). Urbanisation and economic development: A bias toward large cities?. Journal of Urban Economics, 40, 13-37. https://doi.org/10.1006/ juec.1996.0021

Nguyen, H. T. T., Nguyen, C. V., \& Nguyen, C. V. (2020). The Effect of Economic Growth and Urbanization on Poverty Reduction in Vietnam. Journal of Asian Finance, Economics and Business, 7(7), 229-239. https://doi.org/10.13106/ jafeb.2020.vol7.no7.229

Njoh, A. J. (2003). Urbanisation and development in sub-Saharan Africa. Cities, 20, 167-174.

Turok, I., \& McGranahan, G. (2013). Urbanisation and economic growth: The arguments and evidence for Africa and Asia. Environment and Urbanisation, 25, 465-482.

Turok, I., \& McGranahan, G. (2020). Urbanisation and Economic Growth: The Arguments and Evidence for Africa and Asia. Environment \& Urbanization, 4(2), 109-125. https://doi. org/10.1177/2455747119890450

UN World Urbanization Prospects. (2018). UN World Urbanization Prospects: The 2018 Revision. New York, NY: Department of Economic and Social Affairs, Population Division.

Zhao, Y., \& Wang, S. (2015). the Relationship between Urbanization, Economic Growth and Energy Consumption in China: An Econometric Perspective Analysis. Sustainability, 7, 5609-5627; https://doi.org/10.3390/su7055609 